\title{
Knowledge Economy Model for the State of Hidalgo
}

\section{Modelo de economía del conocimiento para el estado de Hidalgo}

\author{
Juan Manuel Lira Aguilar ${ }^{a}$, Sergio Ramses Pons Cabrera ${ }^{b}$, Elías Gaona Rivera ${ }^{c}$
}

\begin{abstract}
:
This article aims to create a knowledge economy model to be applied in the state of Hidalgo, conducting an exhaustive investigation on the formation of a knowledge economy, as well as a comparative analysis between the state of Hidalgo and nine states more than the Mexican Republic with a certain criterion, in relation to the factors that delimit said economy. These factors are a series of variables taken from 2015: literacy, upper secondary and higher education, researchers, Innovation Stimuli Program (PEI), Mixed Fund associated with the state government (FOMIX), telephony, internet, computers, television, patents, industrial designs and utility models. To later use a method created by the World Bank, which is called Knowledge Assessment Methodology (KAM).
\end{abstract}

\section{Keywords:}

Model, Knowledge economy, City of Knowledge, Education, Research and Development

\section{Resumen:}

Este articulo tiene como objetivo la creación de un modelo de economía del conocimiento para que sea aplicado en el estado de Hidalgo, realizando una exhaustiva investigación sobre la conformación de una economía del conocimiento, así como un análisis comparativo entre el estado de Hidalgo y nueve estados más de la república mexicana con un determinado criterio, en relación con los factores que delimitan dicha economía. Estos factores son una serie de variables tomadas del año 2015: alfabetismo, educación media superior y superior, investigadores, Programa de Estímulos a la Innovación (PEI), Fondo Mixto asociado al gobierno estatal (FOMIX), telefonía, internet, computadoras, televisión, patentes, diseños industriales y modelos de utilidad. Para posteriormente emplear un método usado por el Banco Mundial, el cual es denominado KAM por sus siglas en inglés, Knowledge Assessment Methodology.

\section{Palabras Clave:}

Modelo, Economía del conocimiento, Ciudad del Conocimiento, Educación, Investigación y Desarrollo

\section{Introduction}

In 1996 the Organization for Economic Cooperation and Development (OECD) coined the term "knowledge economy" for a group of industrialized countries that recognized knowledge as a determinant of economic growth. The foundations of the knowledge economy rest on the principle of the creation, dissemination and use of knowledge [18]. This economy determines knowledge as the most important asset even above labor and capital goods. The quantity and sophistication of this resource on economic and social activities assumes the level of an economy.

With the arrival of globalization, the tendency for the production of technological knowledge to increase and, furthermore, to spread among the productive sectors, was considered a determining factor for the economic growth of the countries [2]. So then, if knowledge is needed for

\footnotetext{
a Estudiante de Licenciatura en Economía de Noveno Semestre, Universidad Autónoma del Estado de Hidalgo, https://orcid.org/0000-00021686-6357, Email: 1i312436@uaeh.edu.mx

b Estudiante de Licenciatura en Economía de Noveno Semestre, Universidad Autónoma del Estado de Hidalgo, https://orcid.org/0000-00031142-7299, Email: po316125@uaeh.edu.mx

Corresponding author, Universidad Autónoma del Estado de Hidalgo, https://orcid.org/0000-0003-2630-219X, Email: elias_gaona3473@uaeh.edu.mx
} 
the economy to flow, what is needed for knowledge to be produced? At first, only technological capacity and investment in knowledge were taken into account. Today it is known that all this is only a small part, since, not only is it necessary to invest in it and have technology, it is also necessary to train people so that they can produce it (through quality knowledge systems and better incentives to researchers).

The development of the regions of the State of Hidalgo is not very uniform in terms of knowledge generation. It is possible that this is due to the existence of a key factor; that the more developed cities provide a greater added value to the products and services they produce, thanks to the great intensity of knowledge applied to them. Despite this, the state does not operate like others that, for a long time, already have clear the benefits of having an economy based on knowledge.

In recent years, this idea has been mentioned, emphasizing the importance of technological and scientific development, however, in Hidalgo there has not been a significant boost that postulates it as a solid knowledge economy. Chen and Dahlman [18] point out that countries such as South Korea and Ireland have managed to sustain their economic development based on knowledge to achieve everything that was previously stated was impossible. All this thanks to the idea that longterm changes are capable of transforming a society if it has the right tools and the right model.

In the present work it is intended to explore important data about the concept of the knowledge economy, as well as the conception of these ideas in Mexico and Hidalgo. For this effects, the present article is divided into a series of sections: The state of the art, consists of a preliminary analysis that explains how the subject of the knowledge economy has been approached, both historically and in the geographical context of Mexico. Likewise, we address the comparison between the neoclassical model and the new endogenous growth theory, in addition to explaining the structuring of cities of knowledge in Mexico, highlighting the one found in the state of Hidalgo, and the formation of an economy model based on knowledge.

Later, the reason for our research is justified with a brief explanation, and we proceed to the analysis of the indicators considered key in the generation of a knowledge-based economy. The foregoing with the aim of generating a model capable of explaining where Hidalgo is with respect to this type of economy, what its behavior has been in terms of knowledge development and generating proposals that help boost state economic growth.

\section{State of the art}

\section{Preliminary notions of the knowledge economy}

Knowledge is one of the most important commercial assets in the economic development of various regions today. Its production ranges from the educational field to technological innovation and research. As stated by Aboites and Soria (2008), knowledge is considered a nonexclusive and non-rival good for its consumption, since it is possible to use it in different places at the same time and, in addition, there is no absolute control of those who benefit from it [2].

For the production of knowledge to be more efficient, it is essential to use as input all the knowledge already generated throughout history. The consideration of knowledge as a good date back to the 19th century, when certain areas began to emerge where the production of this resource, as well as the invention of techniques for industrial and military empowerment purposes, were its main objective. An example of this, Narváez (2007) mentions, was the United States National Academy of Sciences, built in 1863 to increase the nation's military level during the Civil War [15].

Peenemünde, Germany, was the first city dedicated to scientific and technological research and development in the modern world. This city was in charge of establishing the bases for the empowerment of the Germanic country during World War II in order to carry out a war campaign against the Soviet Union.

After the dissipation of the conflicts that caused the Cold War, the cities dedicated to the production of knowledge became present as an option for economic growth due to the new neoliberal policies, the expansion of commercial areas and the acceleration of the processes of globalization, promoted the industrial development of first world countries.

One of the most notable examples according to Narváez (2007), is the development of Silicon Valley, in California, United States. In this area, under the support of Stanford University, several companies were developed under the command of the students of the aforementioned institution, in order for them to remain in the area and not emigrate to other regions of the country [15].

\section{The neoclassical model and the new endogenous growth theory}

Now we will talk briefly about neoclassical growth models, which, as is well known, focus their study on the accumulation of physical capital characterized by diminishing returns, which implies that physical investment is not capable of causing a growth of the economy in the long run. In other words, according to Thirlwall [18], once work and income have been remunerated to capital, the product of the economy ends, that is, the resource for financing the technological process is extinguished, assuming this as an exogenous variable, as pointed out by neoclassical economists. 
According to Freeman and Pérez [18], other neoKeynesian macroeconomic analyzes determine that there are only restricted models for the quantitative aspects of investment and employment, leaving all qualitative aspects as questions, as is the case of technological change.

For the aforementioned, this consolidates a contradictory thought with the neoclassical and Keynesian theories, in which it was argued that technological change should be related to economic growth. Subsequently, other studies emerged that did not find the convergence of per capita income among the world's economies. Some of them were the new endogenous growth models developed by Robert Lucas in 1988 and Paul Romer in 1986 and 1990, who determined the presence of positive externalities correlated with the production of human capital such as education, improvement and worker training, and research, as well as topics related to the marginal product of capital and the increase in the capital-product rate [18].

\section{Knowledge Cities}

Although the development of knowledge cities is an interesting and worthy topic for discussion, it is also too recent, so different developing societies are barely learning about its potential, including Mexico [10].

Throughout its territory, Mexico boasts three science parks assigned to the category of full members, in addition to another four in the category of affiliate members, within the International Association of Science Parks and Areas of Innovation (IASP).

The emergence of the first City of Knowledge in Mexico took place in the State of Nuevo León with the "Monterrey International City of Knowledge" [10]. This project was born in the six-year term of José Natividad González (2003-2009) as governor, when the Institute for Innovation and Technology Transfer of State promoted its creation with two fundamental purposes; increase the state's per capita Gross Domestic Product (GDP) through knowledge production activities, and foster a culture of innovation in the state.

In 2013 in Jalisco the project "Guadalajara, City of Knowledge" was developed. What was sought with this plan was to promote economic development, as well as promote innovation and research. During the period 20092011, the foundation "Strategic Plan of Yucatan", in conjunction with the Research Center of Yucatan ", proposed the so-called" Mérida International City of Knowledge "whose objective was to integrate the entity into the business of the economy knowledge-based. Cities such as Tepic, Guanajuato, Ciudad Juárez, Querétaro and Torreón, also opted for this type of development focused on the knowledge-based economy, however, they presented deviations in which they ended up as a different model from the one planned or, failing that, they ended up static for administrative reasons [10].

During 2012, the Legislative Assembly of the Federal District presented the Law for the Development of the Federal District, in order to give the guidelines to turn the current Mexico City into a digital and knowledge city. Among its primary objectives were to develop accessible technological infrastructure for citizens, train new professional profiles, promote digital culture, promote the culture of innovation, as well as add value to knowledge and, finally, create companies aimed at creating of knowledge.

The most recent project in Mexico in terms of cities of knowledge is that of "Pachuca City of Knowledge and Culture" in the State of Hidalgo. This work began to take shape in 2011 [10], guided by various models in its planning, such as Europeans, Asians and Americans. However, and according to an interview with Mtro. Alejandro Franco Segura the greatest inspiration in the constitution of this city came from the "City of Knowledge" of Panama.

The City of Knowledge is, without a doubt, one of the oldest projects related to cities of knowledge that has ever been carried out. Its construction begins with a business conception of a "Socratic society", which little by little, by 1995, became a small foundation with the name already described and which, by 1999, was already a well-founded project [6]. The space for this construction has the function of giving the opportunity to scientists, businessmen, analysts, national and international organizations, etc., to promote a social change from innovation.

The City of Knowledge and Culture of Hidalgo is considered a Technopole that serves as a link between companies, government entities, universities to generate an economy based on knowledge through programs, plans and strategies with a high commitment in its design and sustainability. environmental [12].

The project has areas of opportunity that, given the current trends and the revitalized vision that is being printed on the organization, augurs a promising future for the articulation of company-government-universities-society.

\section{Conformation of a knowledge-based model}

According to the World Bank (2007), a knowledge economy underlies 4 main strata, which indicate that knowledge must be acquired, created, disseminated and applied as a vehicle to achieve better economic development within a society. Each is briefly described below.

Human capital is the proverb of knowledge, which requires an intensive use of it, thus, a population with a higher percentage of education and with extensive skills in the creation and acquisition of human capital, is the cornerstone of the production of knowledge. It is possible 
to conclude that the higher the productivity, the higher the economic growth.

In the construction of knowledge-based economy models, human capital is embodied in scientific researchers. That is why illustration 1 shows the evolution of the number of researchers assigned to the National System of Researchers (SNI) of the National Council of Science and Technology (Conacyt), that is, of the magnitude of human capital that collaborates in the creation of knowledge for the specific case of the State of Hidalgo.

Illustration 1 Historical series of the number of researchers registered in the SNI in the State of Hidalgo, $2004-2020$

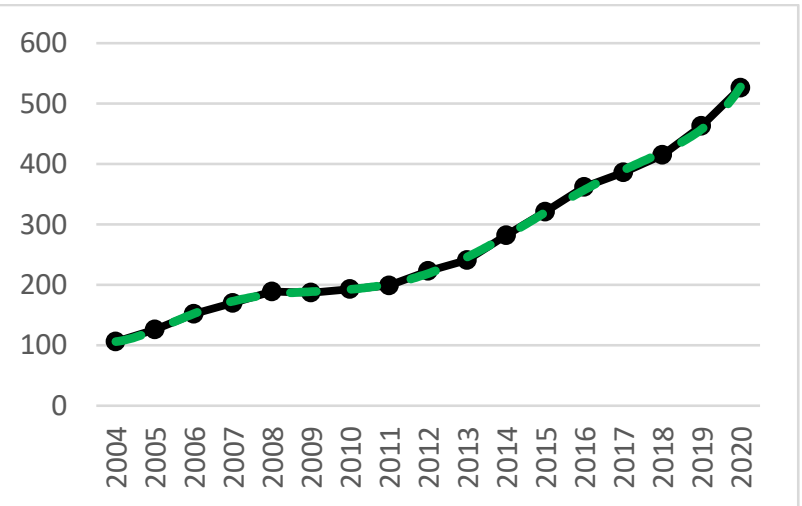

Source: Information consulted from the SNI belonging to CONACYT, in the filter of the number of researchers by federal entity in Hidalgo, own realization).

As can be seen in the illustration above, from 2004 to 2020, the number of researchers from Hidalgo who belong to the SNI has increased at a good rate, surpassing 500 members in the last year. Some studies indicate that human capital is a determining factor in the economic performance of a country. Sánchez (2011) [18] raises in his article "The knowledge economy as the basis of economic growth in Mexico", the importance of education in the construction of a knowledge index, which takes as a reference to literacy, upper secondary and higher education, inter alia.

Other components that are indicated in the model proposed by Herrera (n.d.), is competitiveness, foreign orientation and international attractiveness [11]. As is known, competitiveness constitutes the strength of the economy as a triggering factor for the improvement and strengthening of the various economies through competition, relying on public policy. On the other hand, an attraction, in terms of the knowledge economy, is the ability to create a secure environment capable of attracting foreign direct investment to a region. Orientation to the exterior can be referred to as the end of the productive activity of a region in the direction of international markets. The next component is the presence of innovation systems and the entrepreneurial capacity of a region whose purpose is to generate economic competition when process and product innovation occurs in third parties that incurs in the change and reduction of prices in production. In the case of the State of Hidalgo, the attributions in matters of scientific and technological research are in charge of the Council of Science, Technology and Innovation of the State of Hidalgo (CITNOVA), and as a sub-element of this, there is the aforementioned project "Ciudad of Knowledge and Culture". To this innovation system are added the universities that, although not all carry out research, contribute to the system the graduation of students trained in areas such as business, computer systems, engineering, health sciences, business, among others, that help create a more productive Hidalgo. In Illustration 2 you can see how Pachuca, the capital of Hidalgo, has the highest concentration of universities in the State, having 23 higher education institutions, of the 58 registered in the Cultural Information System (SIC).

\section{Illustration 2 Distribution of educational institutions in the State of Hidalgo by municipality.}

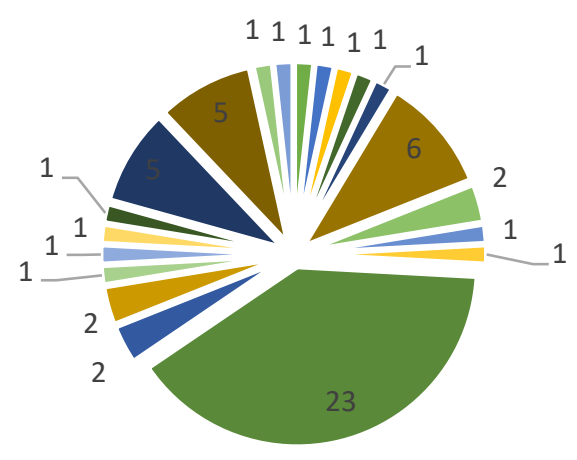

$\begin{array}{ll}\text { - Actopan } & \text { - Apan } \\ \text { - Atotonilco de Tula } & \text { - Ciudad Sahagún } \\ \text { - Francisco I. Madero } & \text { - Huejutla de Reyes } \\ \text { - Huichapan } & \text { - Ixmiquilpan } \\ \text { - Mixquiahuala } & \text { - Pachuca de Soto } \\ \text { - Progreso de Obregón } & \text { - San Agustín Tlaxiaca } \\ \text { - Tepeji del Rio de Ocampo } & \text { - Tizayuca } \\ \text { - Tlahuelilpan } & \text { - Tolcayuca } \\ \text { - Tula de Allende } & \text { - Tulancingo de Bravo } \\ \text { - Zacualtipán de Ángeles } & \text { - Zimapán }\end{array}$

Source: Information obtained from the Cultural Information System, section of Hidalgo universities, own realization.

Finally, the system is also influenced by those companies that have lines of research or are dedicated to creating innovative processes in the State. According to the National Registry of Scientific and Technological 
Institutions and Companies (RENIECyT), by the end of 2020, in Hidalgo there were already 370 companies and scientific and technological institutions registered, most of them not belonging to a sector. The sector to which the most companies belong is professional, scientific and technical services.

Illustration 3 Scientific and technological institutions and companies in Hidalgo by sector to which they belong.

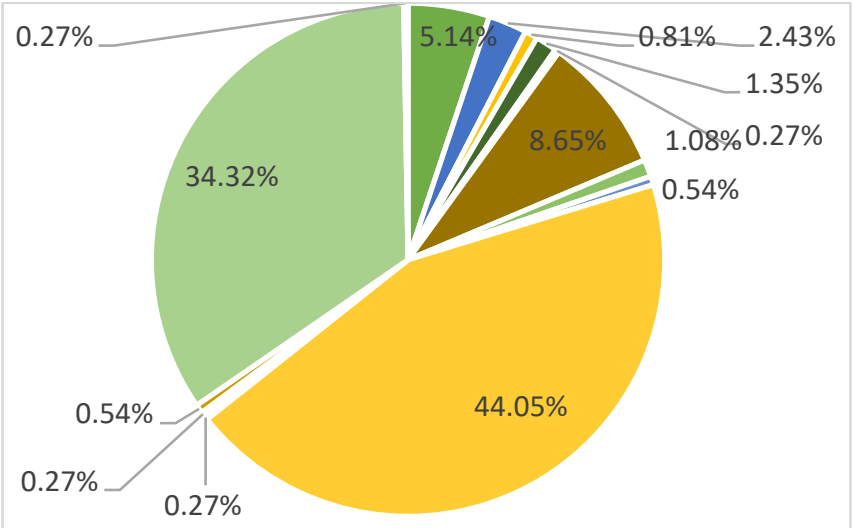

- AGRICULTURE, ANIMAL BREEDING AND EXPLOITATION, FOREST USE, FISHING AND HUNTING

- WHOLESALE TRADE

- RETAIL TRADE

- BUILDING

- GENERATION, TRANSMISSION AND DISTRIBUTION OF ELECTRICAL ENERGY, SUPPLY OF WATER AND GAS BY DUCTS TO THE FINAL CONSUMER

- MANUFACTURING INDUSTRIES

- INFORMATION IN THE MASS MEDIA

- MINING

NONE

- BUSINESS SUPPORT SERVICES AND WASTE AND WASTE MANAGEMENT, AND REMEDIATION SERVICES

- HEALTH AND SOCIAL ASSISTANCE SERVICES

- EDUCATIONAL SERVICES

- SERVICES PROFESSIONALS, SCIENTISTS AND TECHNICALS

- TRANSPORTATION, POST AND STORAGE
Source: Information obtained under the RENIECYT search filter, belonging to CONACYT, regarding scientific and tecnological institucions and companies in Hidalgo, own realization.

The last component that is studied is the information, communication and technology infrastructure that was mentioned above [18]. In creating an index of knowledge, the production of information and communication technologies are of vital importance. It is a fact that the use of knowledge in economic activity is based mainly on the ability to process large information flows, as well as the possibility of using and instantly accessing large databases and administrative systems that help improve of the production [5].

From 2015 to 2018 in Hidalgo, ICT users were distributed in the manner described in Illustration 4. It shows a great growth in user from 2015 to 2016, while for subsequent years the behavior seems to remain almost constant, totaling $62 \%$ in 2018.

Illustration 4 Percentage of Hidalgo households that have access to Digital Television. 2015 - 2018.

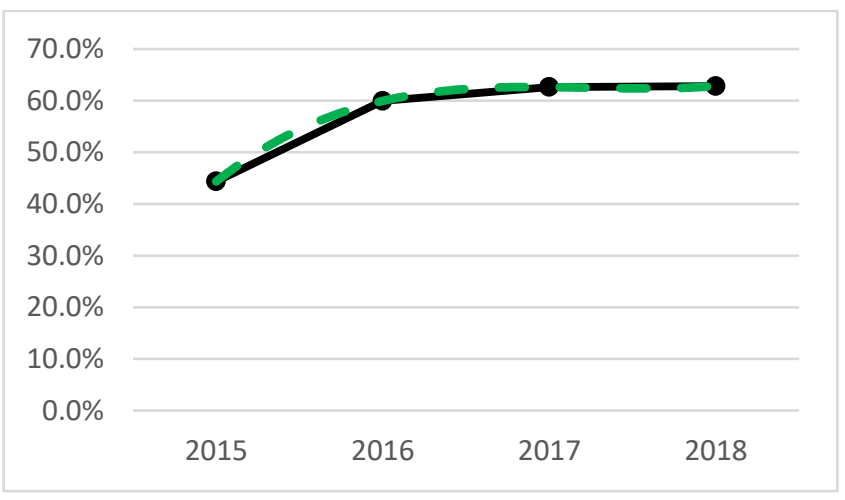

Source: Information obtained from the Telecommunications Information Bank (BIT), belonging to the Federal

Telecommunications Institute (IFT), in the section on surveys / indicators of availability and use of information technologies / Hidalgo, own realization.

In the field of mobile phone users, the trajectory is shaping up to oscillate, reaching its highest trend level in 2017 with 86.8\% penetration and while for 2018 it is down again.

Illustration 5 Percentage of Hidalgo households that have mobile telephone services, 2015-2018.

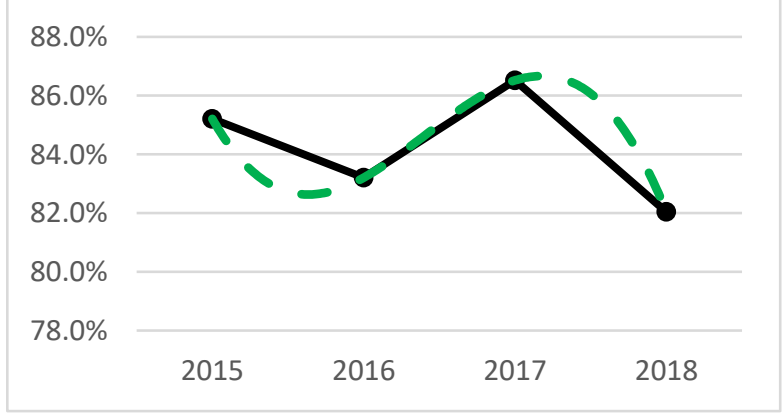


Source: Information obtained from the Telecommunications Information Bank (BIT), belonging to the Federal

Telecommunications Institute (IFT), in the section on surveys / indicators of availability and use of information technologies / Hidalgo, own realization.

Now, the path taken by the trend of users who own a computer is parabolic (see Illustration 6), whose maximum level is $39 \%$ of households in Hidalgo in mid-2016.

\section{Illustration 6 Percentage of Hidalgo households that have} a personal computer, 2015 - 2018

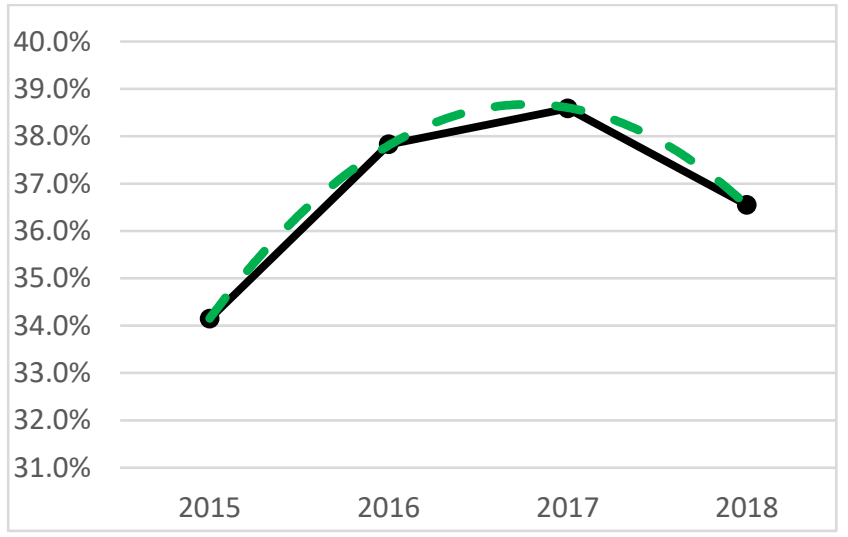

Source: Information obtained from the Telecommunications Information Bank (BIT), belonging to the Federal

Telecommunications Institute (IFT), in the section on surveys / indicators of availability and use of information technologies / Hidalgo, own realization.

Finally, in relation to households with internet access, these reached a maximum of $38 \%$ in 2016 , approximately, and a minimum of $33 \%$ in 2017, continuing to rise for 2018.

Illustration 7 Percentage of Hidalgo households with fixed internet access, 2015 - 2018.

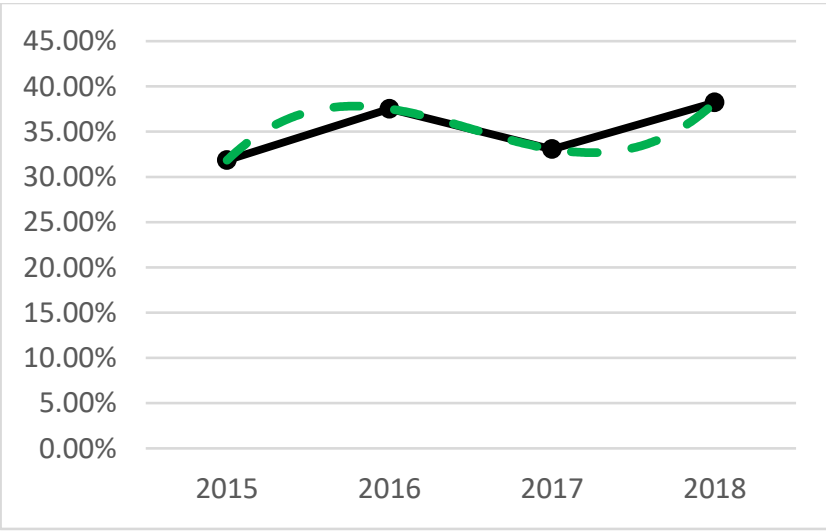

Source: Information obtained from the Telecommunications Information Bank (BIT), belonging to the Federal

Telecommunications Institute (IFT), in the section on surveys / indicators of availability and use of information technologies / Hidalgo, own realization.

\section{Justification}

As mentioned at the beginning of the article, the knowledge economy is a premature and recent topic that has not yet been studied in depth in Mexico, despite the fact that many states have taken the initiative to establish projects that promote culture and bring people closer to the population to issues of innovation, scientific and technological research. In the particular case of Hidalgo, the issue is even more recent than in the rest of the country. This despite the fact that it has been one of the most functional with respect to others that have already stopped operating as cities of knowledge or have changed their nature.

Given the above, it is considered pertinent and timely to formulate a model by which the trajectory that Hidalgo has been taking in its attempt to become a knowledge-based economy is indicated. This analysis aims to take advantage of all the resources that the entity has regarding the pillars of the model proposed by the World Bank, also making a comparison with other entities that are ahead of Hidalgo in aspects such as GDP per capita. The foregoing given the narrowness of its relationship with the development of knowledge-based economies. Do not forget; The higher its development in this area, the higher the GDP per capita [18].

\section{Analysis of variables}

In the analysis presented, a standardization process is used as a methodology for measuring knowledge (Knowledge Assessment Methodology - KAM), created by the World Bank. This methodology allows a holistic view of the factors that affect the knowledge economy, based on the four levels that were described above, with the aim of helping to understand the strengths and weaknesses that characterize Hidalgo with respect to other regions of the country. Likewise, this method will allow the design of public policies in accordance with the problems and opportunities of the state in question, showing the areas in which the need for strategic and governmental intervention is most latent.

It should be mentioned that the variables collected to carry out this research are of a different nature, so a standardization process was used to homogenize all the data on an ordinal scale from 0 (minimum) to 10 (maximum). In this sense, some variables, such as GDP per capita, for example, given in millions of pesos, or the literacy rate expressed as a percentage, were treated mathematically so that they were expressed in the same units.

In this context, the nine States of the Republic with the highest GDP per capita were selected in order to create a comparative framework with Hidalgo, attending to the search for a correlation with respect to the four levels of the knowledge economy. The states chosen for 
jurisdiction: Aguascalientes, Baja California Sur, Campeche, Mexico City, Coahuila de Zaragoza, Nuevo León, Querétaro, Quintana Roo and Sonora. It should be noted that both Nuevo León and Mexico City have implemented models of this kind. On the other hand, States such as Campeche and Quintana Roo are positioned as the largest in terms of economic growth, so the analysis will focus on their situation, with respect to their knowledge economies. The proposed model comprises 19 variables, of which two measure economic growth and seventeen are disaggregated into the four levels that comprise the framework of the knowledge economy.

\section{Standardization Procedure}

The standardization process that was followed to homogenize the study variables is described in the following sections; [7][8]

a) Compilation of raw data (u), obtained from INEGI, Conacyt, Google Public Data and other public agencies.

b) Assignment of ranges in order of relevance for the selected States, according to the values of the raw data $(u)$. The state that has the highest rank will obtain the number 1 (rank $u$ ), until reaching the state that obtains the value of 10 , which will be the entity ranked in the last position (rank u). In this way, States with the same performance are ranked in the same rank.

c) For the state that is in the first position of the ranking, a quotient with value $(\mathrm{Nw})$ is made, which will be given between the total number of States (Nc), minus one of them. For the second entity, the same procedure is followed, however, instead of subtracting one state, two are subtracted, without modifying the denominator $(\mathrm{Nc})$, which is the total number of states. The same procedure is used iteratively for each of the ranked states, until reaching the last one, where the quotient is $(0 / 10)$.

d) Equation one is used to standardize the score of each entity in each of the variables, according to the ranking obtained by each of them and in relation to the total number of states in the sample $(\mathrm{Nc})$;

(standardized $u=10(\mathrm{Nw} / \mathrm{Nc})$ ) (Equation 1)

e) Equation 1 assigns a standardized score between 0 and 10 to each of the states in the sample. The states that are in a favorable position will receive the highest scores, otherwise they will obtain the lowest scores.
Table 1 Variables of the Knowledge Economy Model for the State of Hidalgo.

\section{Economic growth}

- Average Annual GDP Growth Rate Percentage, 2004 - 2015.

- GDP per capita - Amount (current pesos), $2004-2015$.

The national educational, training and training base

- Literacy - Percentage of people aged 15 and over who are literate, 2015.

- Upper secondary education - Percentage of the population aged 15 years and over with upper secondary education, 2015.

- Higher education - Percentage of the population aged 15 and over with higher education, 2015.

\section{Infrastructure for access to information and} telecommunications

- Telephone Users - Percentage of the population with access to telephony, 2015.

- Computer Users - Percentage of the population with access to telephony, 2015.

- Internet users - Percentage of the population with access to telephony, 2015.

- Television users - Percentage of the population with access to telephony, 2015.

\section{Innovation system}

- R\&D expenditure - Amount (millions of current pesos), 2015 - 2021.

- Number of researchers registered in the National System of Researchers (SNI), 2004 2020.

- Private Investment in PEI - Investment contributed by companies in the Innovation Stimulus Program (millions of current pesos), 2015.

- Public Investment in PEI - Investment contributed by the public sector in the Innovation Stimulus Program (millions of current pesos), 2015.

- National Scholars - Number of students benefited by CONACYT's postgraduate scholarship program, 2015.

- FOMIX, Amount - Sum of the support provided by the Mixed Fund associated with the state government (millions of pesos), 2015.

- FOMIX, Number of grants - Number of grants granted by the Mixed Fund associated with the state government, 2015.

- Patents: Exclusive right granted by the state to protect an invention.

- Industrial Designs: Right that protects the design of non-utilitarian objects. 
- Utility models: Industrial property titles that protect inventions of low creative value.

\section{Government institutional frameworks}

- For the purpose of this research, quantitative variables of this nature were not included.

Source: Own elaboration based on data mostly obtained from the National Institute of Statistics and Geography (INEGI), National Council of Science and Technology

(CONACYT) and the Federal Institute of Telecommunications.

\section{Analysis results}

Through Illustration 8 it is possible to know the scores that each state totaled in the present analysis. The center of the graph shows the standardized minimum value (0), while the outer perimeter represents the maximum value (10). The further from the center a score is, the greater the willingness to build a knowledge economy. It was observed that, despite the fact that some states had higher GDP per capita, their knowledge indexes were the lowest. This means that richer states do not necessarily have better knowledge-based economies.

As far as economic growth is concerned, the two variables referring to this section yielded the following results. The entity that ranked first in GDP per capita was Campeche and the last place was obtained by Hidalgo. Regarding the manual average rate of GDP growth, Campeche ranked last with a negative rate of $-6.61 \%$, while Querétaro ranked first. Hidalgo ranked fifth with a rate of $3.87 \%$. Regarding the variables that make up the innovation system, the following finding was obtained; For research and development (R\&D) spending, Mexico City ranked first and Hidalgo third, with a difference of more than $200 \%$, while Baja California Sur ranked last.

Regarding the number of researchers registered in the SNI, Mexico City ranked first with almost 7,900 registered researchers, while Quintana Roo was in the last position with 129. With 321 registered researchers, Hidalgo is in the sixth place. Regarding private investment in PEI, Nuevo León ranked first, Baja California Sur was last and Hidalgo was sixth. On the other hand, in terms of public investment in PEI, Mexico City ranked first, leaving Hidalgo in sixth place and Baja California Sur in the last instance. In the case of the number of students benefited by the CONACYT postgraduate scholarship program, Mexico City once again holds the first place by exceeding 15,000 scholarship recipients, likewise, Hidalgo returned to sixth position with 490 scholarship recipients. The last place went to Campeche with just 73 scholarship recipients.

According to the sum of the support provided by the mixed fund associated with the State Government, Querétaro ranked first, Hidalgo in seventh and Campeche, as well as Mexico City, last. Similarly, in terms of the number of supports provided by FOMIX, as expected, Querétaro is in the first position with 9 supports, while Hidalgo is in sixth place with a total of 2 supports. Regarding patents, Mexico City chairs the ranking, Hidalgo occupies the fifth place and Campeche the last.

Regarding industrial designs, Mexico City once again positioned itself in the first place, Hidalgo in the sixth and Baja California Sur, as well as Campeche, in the last position. Finally, in terms of the utility models variable, Mexico City ranked first with 129 models in 2015, while Hidalgo was six places below with 6 models. Baja California Sur was in the last position as it did not have any utility model.

In education, training and national training, the percentage of people aged 15 years and over with the highest level of literacy, Mexico City reached the highest score, while Campeche the lowest. Hidalgo was positioned in the penultimate place. In relation to the rate of upper secondary and higher education, Hidalgo again occupied the bottom of the list. Regarding the infrastructure of access to information and telecommunications, states such as Aguascalientes and Campeche occupied the last places, while Mexico City and Nuevo León were positioned in the first.

In agreement with mobile phone users, Mexico City ranked first while Hidalgo ranked fifth. In relation to families with access to a computer, Campeche obtained the lowest score while Hidalgo ranked sixth. In terms of internet users, Hidalgo ranked fifth while Campeche once again obtained the lowest score. Finally, when it comes to television users, Hidalgo was fourth in the ranking and Baja California Sur last. 
Illustration 8 Results of the evaluation of knowledge economies, by State, 2015.

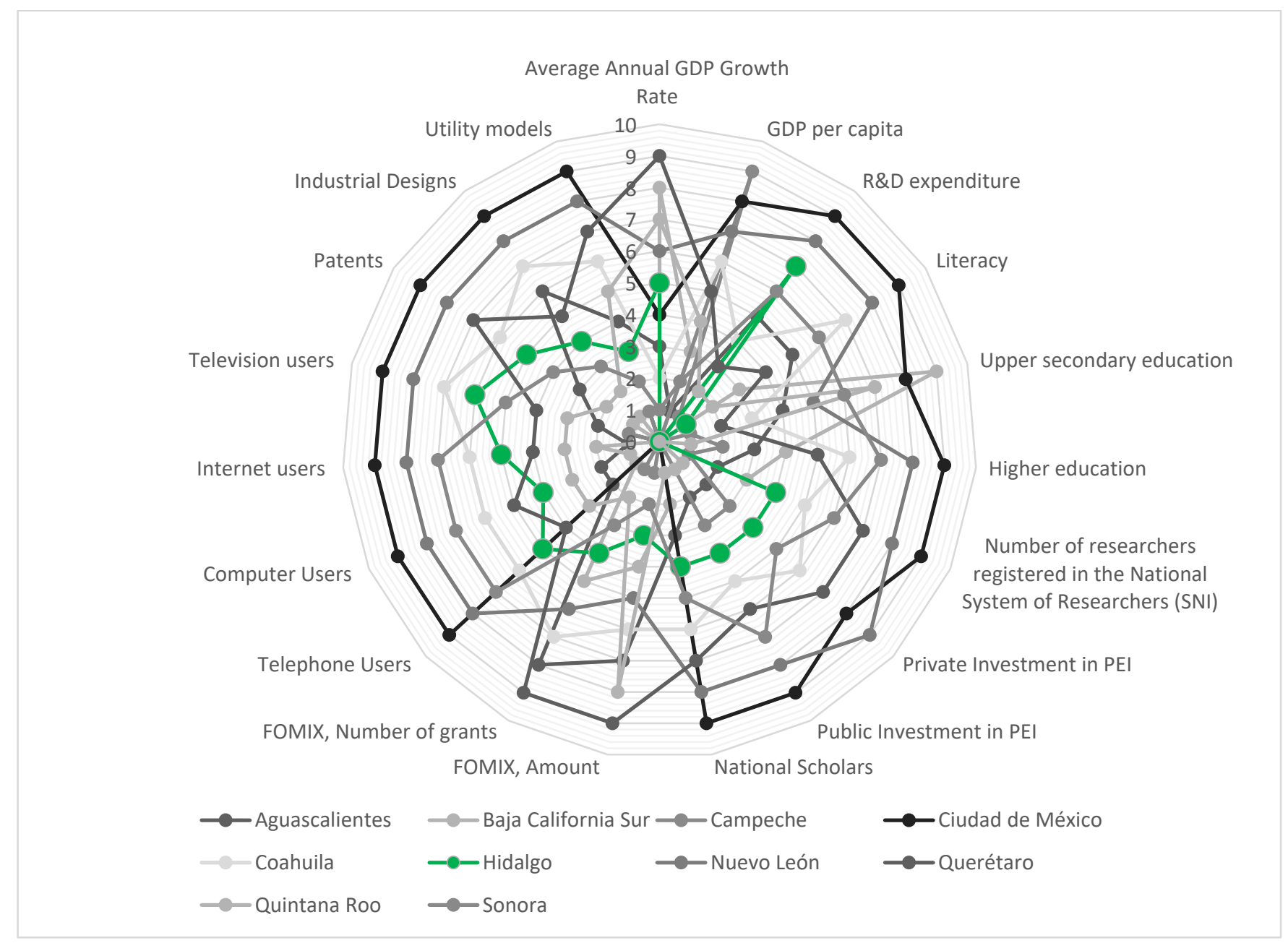

Source: Own creation through the comparison of indicators from various statistical sources.

In the scope of the nineteen variables that were studied, which comprise the levels of a knowledge economy, it is noted that, in the state of Hidalgo, four variables obtained a declining score with respect to the others. These were the percentage of literacy, the proportion of upper secondary level students, as well as the percentage of higher education and, for reasons already mentioned, the GDP per capita. Now a semblance of each of them is offered.

In Gaona's advice (2021), he points out that literacy is an essential factor to eradicate poverty, reduce child abuse, stop demographic growth, establish equality between the sexes and guarantee the sustainable development of peace and democracy. In this sense, being able to read and write is an indispensable condition to be able to participate in the dynamics of the current world, becoming an essential part for the construction of a knowledge economy.

According to the results obtained from the knowledge index, in 2015, Hidalgo was positioned in the penultimate place in the ranking, showing that one of its most latent problems is the inefficient and ineffective basic education system that it has, translating this into a great challenge for the state administration, since, if the adult literacy rate is increased to $100 \%$, the efficiency of education would increase and public spending within a state growth scheme would improve. For this, it is essential to consider which investments in primary education will yield positive returns in the short and medium term at the economic and social level.

As if that were not enough, the figures produced by the study indicate that beyond the precarious level of literacy, there are also deficiencies in upper secondary and higher education because in some cases, the index of both variables obtained a value of zero. As mentioned above, the state must assume great responsibilities when carrying out a public policy. An improvement in higher education will bring as a consequence the technological innovation that the state needs to get out of underdevelopment and join a world competition in the global market.

In the same way, not only the Government must intervene, but the Universities as sources of knowledge must assume 
their role as leader and promote a change in society in the economic and cultural framework. This is why higher education plays an important role in the training of professionals who provide critical and creative solutions to both economic and social problems in the short, medium and long term.

According to the figures estimated by INEGI, the GDP per capita of Hidalgo in 2015 was 6,547.56 dollars, positioning the State in tenth place compared to the 9 states with the highest GDP per capita in the country in the same year. For the purposes of this study, the utility of this variable was considered due to its function of expressing the economic potential of a region. Since the standard of living generally tends to increase as per capita GDP increases, this indicator was considered as an indirect measure of the quality of life of the population in an economy. For these reasons, this variable was used for the construction of a Knowledge Economy Model for the State of Hidalgo.

\section{Conclusions and proposals}

According to the findings of the present study, it is found that Hidalgo has great deficiencies in the education sector, obtaining the lowest scores in the indicators referring to upper secondary and higher education and literacy. This is due to the poor distribution of educational centers and the few resources available to localities in the north of the State, since most of the educational spaces are located in the metropolitan area of Pachuca and its surroundings. On the other hand, since the population of the towns furthest from the capital of Hidalgo is in poverty conditions, they lose the opportunity to study while attending to other essential needs.

It is proposed that the Government of Hidalgo design and implement support aimed at the northern part of the state with the aim of increasing its opportunities, so that young people from Hidalgo in a situation of poverty can access quality education without moving kilometers. In addition, the construction of closer educational centers for the inhabitants of the northern zone is proposed. According to what has been studied, Hidalgo is not so far behind in the block of the use of the infrastructure for access to information and telecommunications, so it is proposed to create awareness and teaching campaigns on the benefits and use of Information and Communication Technologies (ICT).

From the point of view of innovation, there is an incipient interest in spending on R\&D by the government, however, in terms of investment in PEI, whether public or private, it is not high compared to the other entities. Likewise, the number of national scholarship holders and researchers registered in the SNI, who make up the human capital of Hidalgo in terms of knowledge generation, is extremely low. The FOMIX is in the same situation. Finally, patent applications from Hidalgo are very rare. Given this, the opening of investment projects in state PEls is proposed, as well as the promotion of economic support to researchers and inventors from Hidalgo.

For the normative question regarding the institutional framework of the government, the aspects related to the knowledge-based economy are governed by the "Law of Science and Technology of Mexico" and the "Law of Science, Technology and Innovation of the State of Hidalgo" , which do not cover all the issues of managing a knowledge-based economy, so it is proposed to design legislation with a majority focus on the production of knowledge and regulation of support, such as funds and investments in benefit of research and development of knowledge.

From the above emerges a fundamental questioning; if education, the innovation system, the use of ICT, and the government's regulatory framework are strengthened in such a way that they support the state of Hidalgo to become a knowledge-based economy. If this question is true, then there will be economic growth reflected in the average annual growth rate of GDP, as well as in GDP per capita, this being the objective pursued by the knowledgebased model.

\section{Referencias}

[1] (INEGI), s.f. Banco de Indicadores. [En línea] Available at: https://www.inegi.org.mx/app/indicadores/, (consultado el 15 de Marzo del 2021)

[2] Aboites, J. \& Soria, M., 2008. Economía del Conocimiento y Propiedad Intelectual. México : Siglo XXI

[3] Aguascalientes, 31 de Diciembre de 2014. PERIÓDICO OFICIAL DEL ESTADO DE AGUASCALIENTES, Aguascalientes: s.n.

[4] Campeche, 31 de Diciembre del 2014. PERIÓDICO OFICIAL DEL ESTADO DE CAMPECHE, Campeche: s.n.

[5] Cejas, M., 2015. La economía del conocimiento y la investigación: ejes resolutivos de la vinculación con la empresa universidad y la sociedad. Revista Mexicana de Ciencias Agricolas, pp. 91-97.

[6] Ciudad del Saber, s.f. ¿Qué es ciudad del saber?. [En línea] Available at: https://ciudaddelsaber.org/que-es-ciudad-del-saber/, (consultado el 15 de Marzo del 2021)

[7] Gaona, E., González, D. X. \& Sierra, J. M., 2017. Economía del conocimiento El caso de México en comparación con seis países. CIMEXUS, pp. 65-82.

[8] Gaona, E., Vázquez, A. M. \& Rodrígez, E., 2019. Hidalgo: dasfios del desarrollo. Pachuca de Soto: Fondo Editorial.

[9] Google, s.f. Programas del CONACYT. [En línea] Available at: https://www.google.com/publicdata/explore?ds=cnkd64ja0fa0u . (consultado el 15 de Marzo del 2021)

[10] Hernández, N., 2017. Ciudades de Conocimiento en México una Revisión Entre la Teoría y la Práctica. Revista Mexicana de Análisis Político y Administracion Publica, pp. 95-108.

[11] Herrera, D. M., s.f. La Economía basada en el Conocimiento: su conceptualización en México. [En línea] Available at: https://docplayer.es/39243454-La-economia-basada-enel-conocimiento-su-conceptualizacion-en-mexico-por-dulce-mariaherrera-guilhoux.html, (consultado el 15 de Marzo del 2021)

[12] Hidalgo, 31 de Diciembre del 2014. PERIÓDICO OFICIAL DEL ESTADO DE HIDALGO, Pachuca de Soto: s.n.

[13] León, 31 de Diciembre del 2014. PERIÓDICO OFICIAL DEL ESTADO DE NUEVO LEÓN, Monterrey: s.n. 
[14] México, 31 de Diciembre del 2014. PERIÓDICO OFICIAL DE LA CIUDAD DE MÉXICO, Ciudad de México: s.n.

[15] Narváes, A. B., 2007. Ciudades del Conocimiento. México: Universidad Autónoma del Estado de Nuevo León .

[16] Querétaro, 31 de Diciembre del 2014. PERIÓDICO OFICIAL DEL ESTADO DE QUERÉTARO, Santiago de Querétaro: s.n.

[17] Roo, 31 de Diciembre del 2014. PERIÓDICO OFICIAL DEL ESTADO DE OUINTANA ROO, Chetumal: s.n.

[18] Sánchez, C. \& Ríos, H., 2011. La economía del conocimiento como base del crecimiento económico en México.Enl@ce Revista Venezolana de Información, Tecnologíca y Conocimiento, pp. 43-60.

[19] Sistema Integrado de Información Sobre Investigación Científica, s.f. Estadísticas. [En línea] Available at: https://www.siicyt.gob.mx/index.php/estadisticas, (consultado el 15 de Marzo del 2021)

[20] Sonora, 31 de Diciembre del 2014. PERIÓDICO OFICIAL DEL ESTADO DE SONORA, Hermosillo: s.n.

[21] Sur, 31 de Diciembre del 2014. PERIÓDICO OFICIAL DEL ESTADO DE BAJA CALIFORNIA SUR, La Paz: s.n.

[22] Telecominicaciones, 2019. Evolución de las TIC en los hogares por entidad federativa. [En línea] Available at: https://bit.ift.org.mx/SASVisualAnalyticsViewer/VisualAnalyticsVie wer guest.jsp?reportSBIP=SBIP\%3A\%2F\%2FMETASERVER\%2F Shared\%20Data\%2FSAS\%20Visual\%20Analytics\%2FReportes\%2F ENDUTIH(Report)\&page=vi61101\&sso guest=true\&informationEn abled=false\&commentsEnabled, (consultado el 15 de Marzo del 2021)

[23] Zaragoza, 31 de Diciembre del 2014. PERIÓDICO OFICIAL DEL ESTADO DE COAHUILA DE ZARAGOZA, Saltillo: s.n. 